\title{
SUGAR WATER RATIO SEBAGAI TITIK KENDALI KRITIS PADA PROSES PRODUKSI SUSU KENTAL MANIS: STUDI KASUS DI PERUSAHAAN X
}

\section{Sugar Water Ratio as Critical Control Point in the Production Process of Sweetened Condensed Milk: Case Study in the Company X}

\author{
Elok Waziiroh*, Levy Indrawan Wicaksana \\ Jurusan Teknologi Hasil Pertanian, FTP Universitas Brawijaya Malang \\ JI. Veteran, Malang 65145 \\ *Penulis Korespondensi, Email: elokwz@ub.ac.id
}

\begin{abstract}
ABSTRAK
Pada proses produksi susu kental manis (SKM) terdapat titik kendali kritis untuk menjamin keamanan produk yang perlu dikendalikan. Titik kendali kritis merupakan pengendalian bahaya pada tahapan kritis sehingga dapat mengurangi atau menghilangkan resiko bahaya. Titik kendali kritis yang perlu dikendalikan pada proses produksi SKM adalah Sugar Water Ratio (SWR). SWR merupakan rasio kandungan gula dengan air yang terkandung dalam SKM. Pengaruh SWR terhadap kualitas SKM diuji secara mikrobiologis menggunakan teknik enumerasi. pengujian mikrobiologi dilakukan untuk mendeteksi cemaran Enterobacter, Osmophilic Yeast dan Total Plate Count. Berdasarkan hasil analisis dapat diketahui bahwa SKM dengan nilai SWR 62-64\% aman secara mikrobiologis dikarenakan mampu menghambat pertumbuhan mikroba.
\end{abstract}

Kata kunci: Sugar Water Ratio, Susu Kental Manis, Titik Kendali Kritis, Uji Mikrobiologi

\section{ABSTRACT}

The Critical control point during the process of sweetened condensed milk needs to be controlled in order to ensure product safety. The critical control point is controlling hazards at a critical stage of production to eliminate or reduce the hazard that influences food safety. Sugar Water Ratio (SRW) is one of the critical points in the sweetened condensed milk production. SWR is the ratio of sugar content to water contained in sweetened condensed milk that influences food quality and food safety. The effect of SWR on microbiology number was tested using enumeration techniques. Microbiology testing was carried out to detect Enterobacter contamination, Osmophilic Yeast and Total Plate Count. Based on the result, the SWR value of $62-64 \%$ was microbiologically safe due to its ability to inhibit microbial growth.

Keywords: Sugar Water Ratio, Sweetened Condensed Milk, Critical Control Point, Microbiology Test

\section{PENDAHULUAN}

Susu merupakan salah satu komoditas pangan yang banyak dikonsumsi, baik konsumsi secara personal maupun sebagai bahan baku di industri untuk diolah menjadi produk turunannya. tingginya konsumsi prosuk olahan susu secara global, memicu industri pengolahan susu untuk selalu melakukan inovasi proses dan teknologi.

Tingginya kandungan nutrisi pada susu, menjadikan susu rentan mengalami kontaminasi mikrobiologis yang mampu memperpendek umur simpannya. Hal ini didkung oleh Hill et al., (2012) yang menyatakan bahwa tingginya kandungan gizi pada susu menyebabkan susu dimanfaatkan sebagai media pertumbuhan mikroorganisme patogen. Populasi bakteri dapat berkembang dua kali lipat setiap 30 menit pada suhu $25^{\circ} \mathrm{C}$, dimana pH berkisar antara 
6.0-6.5 (Marandi et al., 2005). Menurut Robinson (2002) untuk meningkatkan umur simapan susu, maka susu diolah menjadi berbagai macam produk olahan. Salah satu produk olahan susu yang digemai masyrakat adalah susu kental manis (SKM).

Pada proses produksi SKM terdapat beberapa titik kendali kritis yang perlu diperhatikan. Titik kendali kritis harus diperhatikan karena dapat mengurangi resiko bahaya sampai batas aman atau menghilangkan resiko bahaya yang ada. Salah satu titik kritis pada proses produksi SKM adalah Sugar Water Ratio (SWR). SWR dinyatakan sebagai titik kendali kritis karena SWR dapat menurunkan jumlah mikroba pada SKM sampai batas aman. Hal tersebut dapat terjadi dikarenakan SWR akan mempengaruhi ketersediaan air bebas yang ada di dalam SKM. Nilai SWR dipengaruhi oleh gula yang ditambahkan pada proses pembuatan SKM. Gula memiliki kemampuan untuk mengikat air, sehingga SKM akan memiliki kandungan air bebas yang rendah, sehingga akan memperpanjang umur simpannya (Varman, 2001).

Pada umumnya SKM memiliki kandungan air bebas yang rendah yaitu sebesar 0.83 , namun tidak semua mikroorganisme dapat dihambat pertumbuhannya. Kerusakan pada SKM biasanya disebabkan oleh osmophilic yeast (Chye et al. 2004).. Yeast ini dapat menyebabkan pembentukan gas, aroma buah dan koagulasi kaleng SKM, adapun koagulai protein dapat menyebabkan terjadinya produksi ethanol. Kondisi tersebut menjadikan produk SKM tidak aman dikonsumsi. Oleh karena itu, tujuan dari penelitian ini memastikan keamanan produk SKM dengan melakukan uji mikrobiologios untuk menentukan kesesuaian SWR SKM di tangki penyimpanan.

\title{
BAHAN DAN METODE
}

\section{Bahan}

Produk SKM yang diuji adalah produk SKM di perusahaan $X$ yang telah melalui proses pencampuran dan disimpan di tangki penyimpanan. Bahan untuk analisis meliputi media TSB (Tryptic Soy Broth), $\mathrm{NaCl}$ 0,9\%, 1\% BaCl2, 1\% H2SO4, air laut steril, akuades, alkohol 70\%, spirtus, BPW (Buffered Pepton Water), violet red bile agar (VRB) PCA (Plate Count Agar), dan alkohol $70 \%$.

\begin{abstract}
Alat
Alat yang digunakan pada penelitian ini adalah timbangan analitik (Mettler), colony counter (Stuart Scientific), hot plate stirrer (IKAMAG RET, Janke and Kuntel), autoclave (Hirayama tipe HL-36Ae), inkubator (WTB binder tipe 53), gelas kimia (Pyrex), erlenmeyer (Pyrex), pipet volum (Pyrex), pipetman (Gilson P1000), pipet kontrol (Brand), tabung reaksi (Pyrex), cawan petri, pipet tetes, blue tip, gelas ukur (Pyrex), pengaduk, termometer, dan bunsen.
\end{abstract}

\section{Metode}

Pengujian jumlah TPC (Turkoglu et al., 2003), Enterobacter (AOAC, 1995) Staphylococcus aureus (SNI 2332.9:201) dan koliform (SNI 2897:2008) menggunakan metode hitungan cawan dengan cara tuang. Pengujian TPC menggunakan media PCA, adapun pengujian jumlah koliform menggunakan media VRB dan Enterobacter sp. menggunakan media TSB. Koloni mikroba yang tumbuh pada tiap cawan sampel dihitung dengan menggunakan colony counter, jumlah koloni mikroba yang dianalisis ialah rentang jumlah antara 30-300 koloni cfu/g, jika jumlah koloni tiap sampel lebih dari $300 \mathrm{cfu} / \mathrm{g}$ dikategorikan turbidimetri (TBUD).

\section{Analisis Data}

Analisis hasil data terhadap TPC, Enterobacter, Staphylococcus aureus, dan koliform dilakukan secara deskriptif. 
Sugar Water Ratio sebagai Titik Kendali Kritis - Waziiroh, dkk Jurnal Pangan dan Agroindustri Vol.7 No.1: 12-17, Januari 2019

\section{HASIL DAN PEMBAHASAN}

\section{Penetapan SWR Sebagai Titik Kendali Kritis}

SKM merupakan produk olahan susu yang diproses dengan cara menguapkan sebagian air pada susu. Berbeda dengan susu evaporasi yang mengalami proses sterilisasi untuk memperpanjang umur simpan dan menjaga kualitai, pada SKM dilakukan dengan menambahkan gula konsentrasi tinggi. Dibandingkan dengan produk olahan susu lainnya, SKM memiliki umur simpan yang lebih lama dikarenakan nilai Aw yang rendah. Namun, umur simpan SKM bergantung pada rasio gula yang terkandung di dalamnya. Rasio gula atau biasa disebut SWR berbeda dengan kadar gula. Menurut Othmer (2007) SKM memiliki syarat SWR pada kisaran $62-64,5 \%$. Nilai SWR dapat dihitung dengan menggunakan rumus sebagai berikut:

Ditetapkan SWR sebagai titik kendali kritis dikarenakan nilai SWR pada SKM mampu mempengaruhi kualitas dan umur simpan SKM. Nilai SWR yang ditetapkan oleh Perusahaan $X$ berada di kisaran $62-64 \%$. Keberadaan SWR yang tinggi pada SKM akan menaikan tegangan osmotik pada SKM, sehingga mikroba tidak dapat tumbuh dan produk dapat dikatakan stabil dari kontaminasi mikrobiologi. Selain itu, gula juga memiliki kemampuan untuk mengikat air bebas (bersifat higroskopis) sehingga air bebas pada SKM menjadi lebih rendah. Meskipun selama proses produksi SKM, terdapat tahapan evaporasi namau yang berperan penting dalam menurunkan kandungan air dan menghasilkan produk SKM sampai level aman adalah pengkondisian nilai SWR.

Adanya resiko bahaya karena mikrobiologis menjadi alasan SWR ditetapkan sebagai salah satu titik kendali kritis pada produksi SKM. Oleh sebab itu, dibutuhkan spesifikasi secara mikrobiologis untuk memastikan keamanan produk SKM yang dihasilkan. Menurut Oliver et al., (2005), jumlah mikroorganisme yang terdapat pada susu segar dipengaruhi oleh beberapa faktor, seperti ukuran kandang, jumlah hewan, higiene, praktek manajemen, letak geografi, musim, perbedaan metode deteksi dan variasi sampel. Adapun standar cemaran mikroba SKM dapat dilihat pada Tabel 1.

Tabel 1. Standar Cemaran Mikroba SKM SNI 01-2971-1998

\begin{tabular}{lcc}
\hline Cemaran Mikroba & Satuan & Syarat \\
\hline Total Plate Count & Koloni $/ \mathrm{g}$ & Maks $10^{4}$ \\
Bakteri Coliform & $\mathrm{APM} / \mathrm{g}$ & Maks 10 \\
E. Coli & $\mathrm{APM} / \mathrm{g}$ & $<3$ \\
Salmonella & $\mathrm{Per} 100 \mathrm{~g}$ & Negatif \\
Staphylococcus aureus & Koloni/g & Maks $10^{2}$ \\
Kapang dan khamir & Koloni/g & Maks $10^{2}$ \\
\hline
\end{tabular}

Sumber: Badan Standarisasi Nasional (1998)

Adapun standar cemaran mikrobiologi yang ditetapkan oleh Perusahaan $\mathrm{X}$ disampaikan pada Tabel 2.

Tabel 2. Standar Cemaran Mikroba SKM di Perusahaan X

\begin{tabular}{lcc}
\hline Cemaran Mikroba & Satuan & Syarat \\
\hline Total Plate Count & $\mathrm{cfu} / \mathrm{g}$ & $<10.000$ \\
Enterobacter & $\mathrm{cfu} / 0,5 \mathrm{~g}$ & $<1$ \\
Yeast/Molds & $\mathrm{cfu} / 0,33 \mathrm{~g}$ & $<1$ \\
\hline
\end{tabular}

Berdasarkan standar cemaran mikroba Perusahaan X pada Tabel 2. memiliki standar yang lebih ketat dibandingkan SNI. Cemaran Enterobacter merupakan bakteri gram negatif yang sebagian besar merupakan bakteri patogen seperti Salmonella dan E.Coli. Selain itu juga dilakukan analisis tambahan untuk micrococci dan osmophilic yeast. Dua analisis tersebut dilakukan untuk memastikan bahwa SKM yang diproduksi oleh Perusahaan X telah sesuai dengan standar keamanan dari sisi cemaran mikroba. 
Adapun keberadaan osmophilic yeast dapat menyebabkan terbentuknya gas di dalam kemasan, adanya aroma buah dan koagulasi protein. Koagulasi protein sangat tidak diharapkan karena dapat menyebabkan terjadinya produksi etanol di dalam produk. Hal itu menyebabkan produk tidak dapat diterima oleh konsumen. Selain itu, beberapa microccoci tumbuh di SKM walaupun lambat. Namun, apabila dibiarkan, micrococci dapat menyebebakan koagulasi sehingga menyebabkan munculnya rasa yang tidak diinginkan pada produk akhir.

\section{Pengendalian Titik Kendali Kritis SWR}

Proses pengendalian SWR dilakukan sejak awal penambahan gula, secara umum ada tiga tahapan pengendalian SWR sebagai Critical Control Point (CCP), yaitu:

1. Kontrol

Proses kontrol dilakukan dengan memastikan bahwa gula yang ditambahkan saat proses pencampuran sesuai dengan spesifikasi standar SWR. Gula yang digunakan juga harus dipastikan bebas dari mikroorganisme dan kontaminan lainnya.

2. Monitoring

Proses monitoring dilakukan secara berkala oleh staff yang berpengalaman dan perhitungan SWR harus dilakukan dengan pengawasan staff ahli. Selain itu, monitoring juga dilakukan pada proses penerimaan gula untuk memastikan gula dari supplier telah memenuhi spesifikasi.

3. Verifikasi

Proses verifikasi dilakukan dengan melakukan monitoring secara berkala baik berkaitan dengan nilai SWR dan analisis mikrobiologi.

Pengecekan nilai SWR dilakukan setelah proses pencampuran SKM dengan seeding lactose. Setelah proses pencampuran SKM akan masuk ke dalam tangki penyimpanan dan akan diukur nilai SWR-nya. pengukuran nilai SWR dilakukan secara cepat menggunakan NIRFOSS. Pengukuran nilai SWR harus dilakukan secara cepat karena SKM ayang ada di tangki penyimpanan harus segera dikemas. Apabila nilai SWR tidak sesuai, maka SKM tidak boleh dikemas dan harus dilakukan standarisasi terlebih dahulu sampai disapatkan nilai SWR yang sesuai. Secara umum ada 2 kasus yang terjadi pada titik kendali kritis SWR, yaitu:

a. SWR terlalu tinggi

Apabila nilai SWR pada SKM terlalu tinggi maka akan dilakukan proses pengenceran, kemudian dilakukan proses standarisasi ulang sampai didapatkan nilai SWR yang sesuai dengan spesifikasi. Nilai SWR yang terlalu tinggi akan menyebabkan kristalisasi pada SKM sehingga SKM memiliki tekstur yang berpasir. Kondisi tersebut akan menurunkan kualitas SKM

b. SWR terlalu rendah

Pada kondisi nilai SWR terlalu rendah atau lebih rendah dari spesifikasi yang ditetapkan maka akan dilakukan proses pencampuran antara SKM dengan SWR dengan SKM dari tangki penyimpanan yang lain, sehingga didapatkan nilai SWR sesuai dengan standar.

Analisis mikrobiologis pada setiap tangki penyimpanan SKM tetap dilakukan meskipun nilai SWR-nya telah sesuai dengan stndar. Tujuan pemantauan secara mikrobiologi yaitu untuk memastikan bahwa setiap produk yang dihasilkan terjamin keamananya dan berkualitas. Selain itu, pengecekan mikrobiologi juga dilakukan untuk mrmastikan tidak ada kontaminasi mikroba selama proses produksi berlangsung. Pengecekan mikrobiologi di Perusahaan $X$ dilakukan sebanyak dua kali, yaitu sebelum SKM distandarisasi dan setelah distandarisasi di tangki penyimpanan. 


\section{Korelasi Hasil Pengujian Mikrobiologi dan Nilai SWR}

Tabel 3. Hasil Analisis Mikrobiologi dan SWR pada Tangki Penyimpanan SKM

\begin{tabular}{llcccc}
\hline No & Sampel & SWR (\%) & Entero (Cfu/0,5g) & TPC (Cfu/g) & $\begin{array}{c}\text { Yeast Mold } \\
\text { (Cfu/0,33g) }\end{array}$ \\
\hline 1 & A1 & 64,08 & $<1$ & 210 & $<1$ \\
2 & A1+ & 63,15 & $<1$ & 160 & $<1$ \\
3 & A2 & 63,74 & $<1$ & 390 & $<1$ \\
4 & A2+ & 62,26 & $<1$ & 410 & $<1$ \\
5 & A3 & 64,86 & $<1$ & 80 & $<1$ \\
6 & A3+ & 63,90 & $<1$ & 180 & $<1$ \\
7 & A4 & 63,58 & $<1$ & 20 & $<1$ \\
8 & A4+ & 62,61 & $<1$ & 140 & $<1$ \\
9 & A5 & 62,67 & $<1$ & 290 & $<1$ \\
10 & A5+ & - & & 100 & $<1$ \\
11 & A6 & 63,61 & $<1$ & 70 & $<1$ \\
12 & A6+ & 63,21 & $<1$ & 40 & $<1$ \\
13 & A7 & 63,85 & $<1$ & 100 & $<1$ \\
14 & A7+ & 63,35 & $<1$ & 760 & $<1$ \\
15 & A8 & 62,22 & $<1$ & & \\
\hline 16 & A8+ & \multicolumn{5}{l}{}
\end{tabular}

Berdasarkan data pada Tabel 3, terdapat beberapa sampel yang nilai SWR-nya diatas $64 \%$, adapun sesuai standar nilai SWR berada pada range $62-64 \%$. Oleh karena itu sampel A1 dan A3 yang memiliki nilai SWR berturut-turut $64,08 \%$ dan $64,86 \%$ akan dilakukan proses standarisasi untuk dilakukan penyesuaian nukau SWR. Sampel yang memiliki nilai SWR sesuai standar akan tetap dilakukan pengujian untuk memastikan nilainya telah sesuai dengan standar dan tidak berpengaruh pada kristalisasi produk. kristalisasi dapat berdampak negatif pada penerimaan tekstur produk, sehingga kondisi tersebut dihindari.

Selain dilakukan analisis nilai SWR, juga dilakukan uji mikrobiologi untuk menjamin keamanan produk SKM yang disimpan pada tangki penyimpanan. Berdasarkan data Tabel 3, hasil pengujian Enterobacter kurang dari $1 \mathrm{cfu} / 0,5 \mathrm{~g}$ enterobacter, sehingga dapat dikatakan memenuhi standar dan aman dikonsumsi. Adapun hasil analisis total plate count seluruh sampel juga menunjukkan nilai kurang dari $10.000 \mathrm{cfu} / \mathrm{g}$, hal ini juga didukung dengan hasil analisis kapang dan khamir yang juga sesuai standar.

\section{SIMPULAN}

SWR sebagai titik kendali kritis produk SKM di Perusahaan X telah memenuhi standar range 62-64\%. Berdasarkan hasil analisis mikrobiologi kandungan SWR menurunkan resiko cemaran mikroba. SKM pada tangki penyimpanan telah memenuhi standar keamanan Enterobacter, Total Plate Count, kapang dan khamir.

\section{UCAPAN TERIMA KASIH}

Terimakasi kami ucapkan atas kesempatan penelitian magang yang diberikan oleh Perusahaan X. 


\section{DAFTAR PUSTAKA}

AOAC (Associantion Of Official Analitycal Chemist).1995. Official Methods of Analysis. Washington D.C

Badan Standarisasi Nasional. 1998. SNI 01-2971-1998. Standar Mutu Susu Kental Manis. Jakarta.

Chye FY, Abdullah A, Ayob MK. 2004. Bacteriological Quality and Safety of Raw Milk in Malaysia. Food Microbiol 131: 30-39.

Hill B, Smythe B, Lindsay D, Shepherd J. 2012. Microbiology of Raw Milk in New Zealand. Int J Food Microbiol. 10.1016/j.ijfoodmicro.2012.03.031.

Oliver Sp, Jayarao BM, Almeida RA. 2005. Foodborne Pathogens in Milk and The Dairy Farm Environment: Food Safety and Public Health Implications. Foodborne Pathog Dis 2: 115129.

Othmer, K. 2007. Food and Feed Technology. Wiley Inc.New York

Turkoglu, H., Z. G. Ceylsn, and K. S. Dayisoylu 2003. The Microbiological And Chemical Quality Of Orgu Cheese Produced In Turkey. Pakistan Journal Of Nation 2 (2): 92-94.

Marandi S, Brasca M, Alfieri P, Lodi R, Tamburini A. 2005. Influence of $\mathrm{pH}$ and temperature on the growth of Enterococcus faecium and Enterococcus faecalis. Lait 85: 181-192.

Robinson RK. 2002. Dairy Microbiology Handbook. Ed. Ke-3. New York (US): John Wiley and Sons Inc.

Varman, AH and Jane PS. 2001. Milk and Milk Products: Technology, Chemistry and Micobiology Chapman \& Hall. USA 